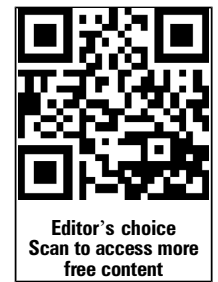

- Additional material is published online only. To view please visit the journal online (http://dx.doi.org/10.1136/ oemed-2013-101908).

For numbered affiliations see end of article.

\section{Correspondence to}

Professor Fernando $\mathrm{G}$

Benavides, CiSAL-

Universitat Pompeu Fabra. Parc de Recerca Biomèdica de Barcelona, Dr Aiguader 88, Barcelona 08003, Spain; fernando.benavides@upf.edu

Received 2 October 2013 Revised 26 February 2014 Accepted 3 March 2014 Published Online First 20 March 2014

\section{SLinked}

http://dx.doi.org/10.1136/ oemed-2014-102223

\section{CrossMark}

To cite: Benavides FG Wesseling C, Delclos GL, et al. Occup Environ Med 2014;71:459-465.

\title{
Working conditions and health in Central America: a survey of 12024 workers in six countries
}

\author{
Fernando G Benavides, ${ }^{1,2,3}$ Catharina Wesseling, ${ }^{4}$ George L Delclos, ${ }^{5,1,2,3}$ \\ Sarah Felknor, ${ }^{5,6}$ Javier Pinilla, ${ }^{7}$ Fernando Rodrigo, ${ }^{1,8}$ on behalf of the research team \\ of the first Central American Survey of Working Conditions and Health
}

\section{ABSTRACT}

Objective To describe the survey methodology and initial general findings of the first Central American Survey of Working Conditions and Health.

Methods A representative sample of 12024 workers was interviewed at home in Costa Rica, El Salvador, Guatemala, Honduras, Nicaragua and Panama. Questionnaire items addressed worker demographics, employment conditions, occupational risk factors and self-perceived health.

Results Overall, self-employment (37\%) is the most frequent type of employment, $8 \%$ of employees lack a work contract and $74 \%$ of the workforce is not covered by social security. These percentages are higher in Guatemala, Honduras and El Salvador, and lower in Costa Rica, Panama and Nicaragua. A third of the workforce works more than $48 \mathrm{~h}$ per week, regardless of gender; this is similar across countries. Women and men report frequent or usual exposures to high ambient temperature (16\% and $25 \%$, respectively), dangerous tools and machinery $(10 \%, 24 \%)$, work on slippery surfaces $(10 \%, 23 \%)$, breathing chemicals $(12.1 \%$, $18 \%)$, handling toxic substances $(5 \%, 12.1 \%)$, heavy loads $(6 \%, 20 \%)$ and repetitive movements $(43 \%$, $49 \%$ ). Two-thirds of the workforce perceive their health as being good or very good, and slightly more than half reports having good mental health.

Conclusions The survey offers, for the first time, comparable data on the work and health status of workers in the formal and informal economy in the six Spanish-speaking Central American countries, based on representative national samples. This provides a benchmark for future monitoring of employment and working conditions across countries.

\section{INTRODUCTION}

Central America contains six Spanish-speaking countries: Guatemala, Honduras, El Salvador, Nicaragua, Costa Rica and Panama. Although countries differ considerably in development index ranging from 0.58 in Guatemala to 0.78 in Panama, ${ }^{1}$ the region has geographic, cultural and economic cohesion. Efforts towards greater integration have been ongoing for over 50 years, ${ }^{2}$ an important tool to eliminate poverty and improve living and working conditions of the Central American population.

In Central America, there is a dearth of information on working conditions and health. ${ }^{3}$ This creates barriers for informed policy decisions to improve health and well-being in this politically and economically important region. The establishment of reliable

\section{What this paper adds}

- As a result of current economic models, informal employment is increasing and thought to be associated with worse working conditions.

- Presently there exists no surveillance of workrelated health effects or hazardous exposures suitable to assist in policy-making, anywhere in Latin America.

- The First Central American Survey of Working Conditions and Health (ECCTS, by its Spanish acronym) offers, for the first time, comparable data on the work and health status of workers in the formal and informal economy in the six Spanish-speaking Central American countries, based on representative national samples.

- The ECCTS underscores the low quality of a large part of employment in Central American countries, with three out of four members of the workforce lacking social security, a third being self-employed, and almost one out of ten salaried employees working without either a written or oral contract.

- The ECCTS provides a reference measure for future monitoring of employment and working conditions across countries.

information systems is a top priority of several global health and development programs, including the United Nations Millennium Development Goals, ${ }^{4}$ the World Health Organization Workers' Health

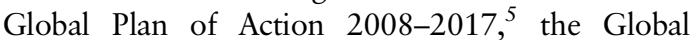
Strategy in Occupational Safety and Health ${ }^{6}$ and the Ibero-American Strategy in Occupational Safety and Health (2010-2013) of the Ibero-American Social Security Organization.

As a result of current economic models favouring external markets with deregulated formal work sectors, productivity and employment have been growing in the Latin American and Caribbean region. ${ }^{8}$ Also, in the context of the free trade agreements between Central America and North America, Europe and other Asian and South American economic blocks, occupational safety and health has become an issue of major relevance. It has been reported, however, that this growth has been accompanied by a general deterioration of working conditions for much of the population in Central America. 
This pattern has also increased informal employment, thought to be associated with worse working conditions for the majority of the working population. ${ }^{9}$

Although more than a decade ago the Pan-American Health Organization began promoting surveillance based on sentinel occupational health events information (fatal occupational injuries, pesticide poisonings and low back pain) in selected Latin American countries as a means to improve prevention and control measures, ${ }^{10}$ surveillance systems have been difficult to implement or to sustain over time. Today, there exists no surveillance of workrelated health effects or hazardous exposures suitable to assist in policymaking, anywhere in Latin America.

Surveys are another tool to monitor workers' conditions and health and, in fact, a common strategy used around the world. The European Working Conditions Survey has been conducted periodically since 1990, the fifth and most recent one in 2010, involving 34 member states. ${ }^{11}$ They provide important prevalence and time trend data on perceptions of workers about a variety of risks and their well-being. The results of these surveys play an important role in defining priorities for more in-depth research and also actions, on national and regional levels.

In Latin America, national surveys on working conditions and health have recently been completed successfully in Colombia, ${ }^{12}$ Argentina, ${ }^{13}$ Chile $^{14}$ and Uruguay, ${ }^{15}$ but none in Central America. These surveys focused primarily on the formal sector because this sector is more accessible from a methodological viewpoint and because the formal sector is traditionally the main or only sector addressed by ministries of labour in Latin America. ${ }^{3}$ In Central America, the informal sector, including those employed in microenterprises, homes and the selfemployed, was reported to be about half of the labour force in $1999^{16}$ and $64 \%$ in $2006 .{ }^{9}$ Therefore, data systems on working conditions and health in Central America must address also informal workers.

Given the lack of reliable and comparable data on work and health in the Central American countries, in 2011 we developed and implemented the First Central American Survey of Working Conditions and Health (ECCTS, by its Spanish acronym), ${ }^{i}$ targeting workers in both the formal and the informal economies. The goals of this paper are to describe the survey methodology and present initial general findings on work and health status in the region.

\section{SUBJECTS AND METHODS \\ Study design and sample}

The ECCTS was a cross-sectional survey of workers aged 18 or older, in the formal and informal economy and all economic activity sectors, who had worked for economic remuneration in the previous week for at least $1 \mathrm{~h}$ in the six Spanish-speaking countries of Central America (ie, excluding Belize).

The total regional sample consisted of 12024 workers (data set is available upon request), applying a similar criterion used by the European Working Conditions Survey, in which the number by country is fixed around 1000 . In our case, in each country, a same size representative sample of 2004 was drawn from the last census data available, randomly selecting 167 census segments from all departments (Guatemala, El Salvador, Honduras y Nicaragua) or provinces (Costa Rica and Panama) proportional to the respective populations in the departments or provinces. Within each sampling segment, 12 households

${ }^{\mathrm{i}}$ Encuesta Centroamericana de Condiciones de Trabajo y Salud. were selected by random block walking. When a household was empty, interviewers returned once; if unsuccessful, the adjacent household was selected (between $47 \%$ in Panama and 32\% in Costa Rica). In each household, only one worker was interviewed. When there was more than one eligible candidate in a household, the one with the nearest birthday was selected. When a worker did not consent participation, he was replaced by the one with the nearest birthday in the same household or someone from the adjacent household. Overall, participation rates before replacement were approximately $50 \%$ in Costa Rica, $60 \%$ in Honduras and $80 \%$ in Guatemala, El Salvador, Nicaragua and Panama.

To correct for differences between the sample and the source population of each country and the region as a whole, each individual included in the sample was weighted by sex, age (18-30, 31-50 and 51-65), economic sector (primary (agricultural), secondary (manufacturing and construction) and tertiary (services)) and country, according to the weighting methodology of the European Working Conditions Surveys. ${ }^{17}$ Weighting by occupational groups would have been useful, but was not possible as this information was not available from the census. Self-employed workers and the other occupational groups were classified into their respective economic activity sectors.

\section{Questionnaire and survey administration}

The questionnaire (available upon request) was designed based on prior review of the questionnaire of the Spanish Survey on Working Conditions (mainly health, safety and psychosocial items), $^{18}{ }^{19}$ the questionnaire of the European Survey on Working Conditions (ergonomic and hygiene items), ${ }^{11}$ the ILO Manual of Occupational Injury Statistics (injury) ${ }^{20}$ and the 12-item General Health Questionnaire (mental health). ${ }^{21}$ The questionnaire was developed in Spanish, pilot tested in 144 persons ( 24 workers per country), fine-tuned to the local terminology of each country and designed so that it would not take more than $30 \mathrm{~min}$ to complete. The questionnaire included 78 items (a table with key dimensions and items is provided as annex 1 available online), grouped into demographics (12), employment conditions (25), working conditions (12) and health-related indicators (29). If workers had more than one job, they were asked to answer the questions related to the job in which they spent the greatest number of hours in the week prior to the survey.

The fieldwork was carried out between July and December 2011. In all countries, the survey was administered by trained interviewers of Borge and Associates (http://www.borgeya.com), a company with extensive survey experience in the region. The local research team in each country closely supervised the data collection for quality assurance.

\section{Measures}

For the purpose of this report, we selected the following measures: sex, age (<30,30-50 and $>50$ years); educational level (illiterate, complete and incomplete primary, secondary school and university); economic activity sectors (primary, secondary and tertiary); and occupational categories according to the International Standard Classification of Occupations: professionals, technicians, administrative support, services and retail sales, farming and fishing, skilled manual workers and unskilled manual workers. $^{22}$

Employment condition questions centred on type of labour relationships (employer with employees, self-employed, permanent and temporary employees), contracts (written, oral, no 
contract), social security (yes/no) and hours worked in a week (cut-off at $48 \mathrm{~h}$ per week). Working conditions addressed the presence of hazards during a usual working day and, if present, more than $50 \%$ of a work shift. Examples include working on a slippery or unstable surface, handling dangerous tools and machines, exposure to high temperatures, inhalation of chemicals, handling of toxic substances, handling of heavy loads and performing repetitive movements.

Self-reported health indicators consisted of self-perceived health (very good or good vs regular or bad health) and mental health (with a score of less than three points indicating good vs bad), occupational injury in the last 12 months resulting in at least 2 days of absence and back pain in the last 4 weeks.

\section{Ethical issues}

Participants were informed of the survey objectives, invited to participate and had their questions answered. Verbal informed consent was given before the interview administration. Participants were provided with a written statement of the purpose of the survey and contact numbers in the country for any further questions or concerns. The project protocol was reviewed and approved by the institutional review boards of the Universidad Nacional in Costa Rica and The University of Texas Health Science Center at Houston.

\section{RESULTS}

\section{Demographic and labour characteristics of the sample}

In the region (figure 1), workers were mostly young, with $85 \%$ of women and $79 \%$ of men under 50 years of age, and educational level was higher among women (13\% university vs 6\% illiterate level) than men ( $8 \%$ vs 9\%, respectively), particularly in Panama, Costa Rica and Nicaragua. By economic activities sector, women worked mainly in the tertiary (service) sector $(77 \%)$ and men in the secondary (service) sector (42\%) and primary (agricultural) sector (37\%), although on national levels, in Panama, Costa Rica and El Salvador a majority of men worked in the services sector (see online annex 2). Female occupations were mainly in retail sales and other services jobs (51\%), whereas men were more frequently farmers (36\%), with a lower proportion in retail sales $(22 \%)$ and skilled manual jobs $(23 \%)$.

\section{Employment and working conditions}

Self-employment (around 37\% among women and men) was the most frequent type of employment in the region (figure 2). Among employees, about $8 \%$ did not have a work contract, whether written or oral. These percentages were higher in Guatemala, Honduras and El Salvador. More than 70\% of the region's workforce works without social security coverage, although there were large differences by country (between 33\% of women and $35 \%$ of men in Costa Rica; and $85 \%$ and $91 \%$ in Honduras). Across all countries and both genders (see online annex 3), a third of the workforce worked more than $48 \mathrm{~h}$ per week.

Regarding safety, ergonomic, hygiene and psychosocial working conditions (figure 3), one-fourth of men in the region and $16 \%$ of women reported being exposed to high ambient temperatures for more than half of a usual working day; $18 \%$ of men and $12 \%$ of women indicated exposure to inhalable chemicals for more than half a typical work shift; and 12\% of men and $5 \%$ of women reported handling toxic substances. Handling heavy load at work was declared by $20 \%$ of men and $6 \%$ of women. These prevalences varied widely by country (see online annex 3 ).

\section{Health-related problems}

Two-thirds of the Central American workforce reported their health as being either good or very good (figure 4), and little more than half the workforce reported having good mental health (54\% in women and 57\% in men). Work-related injuries

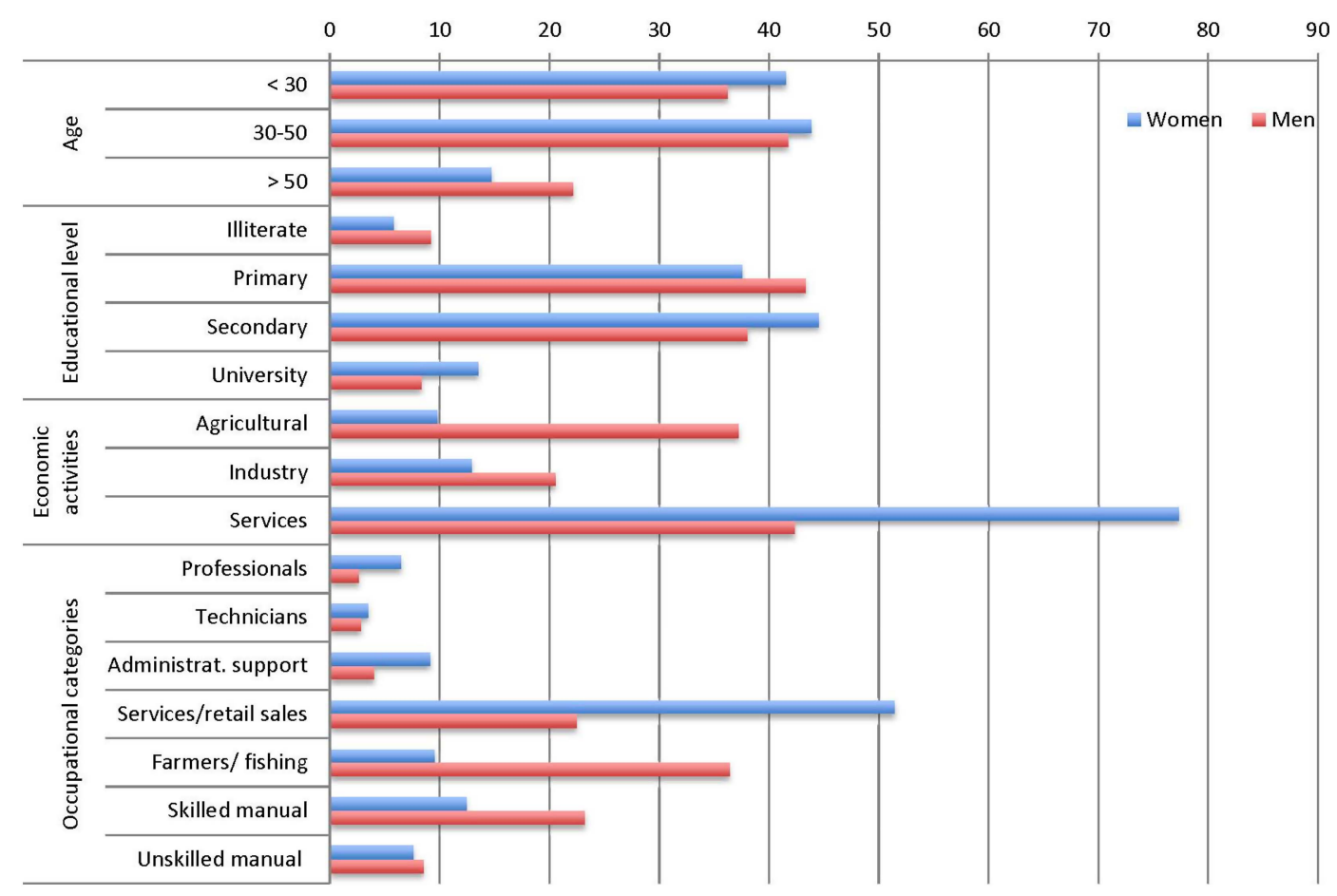

Figure 1 Demographic and labour characteristics by sex at regional level. The First Central American Working Conditions and Health Survey, 2011 $(n=12$ 024). 


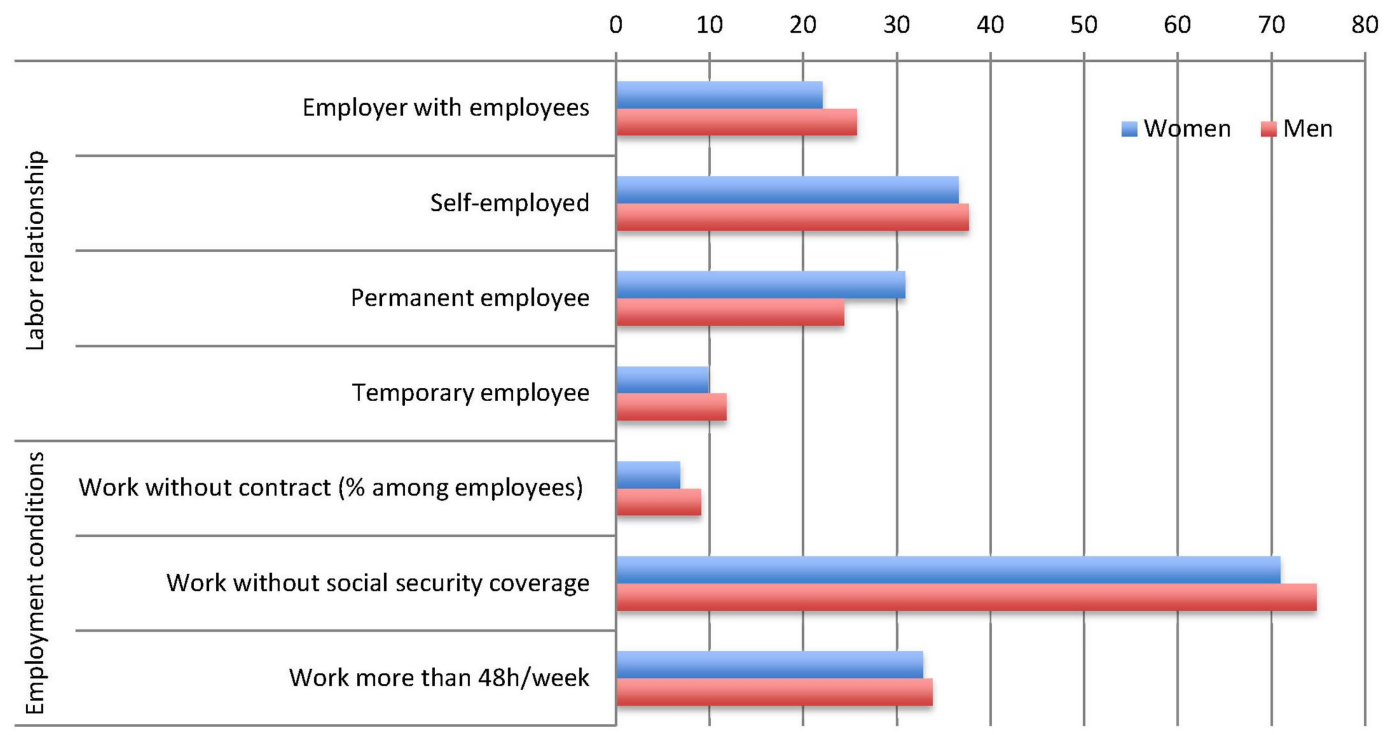

Figure 2 Labour relationship and employment conditions by sex at regional level. The First Central American Working Conditions and Health Survey, $2011(n=12$ 024).

resulting in at least 2 days of absence in the previous year were reported by only 3\% of Central American women and $4 \%$ of men, but on the other back pain in the previous 4 weeks was perceived by more than half the study population $(50 \%$ of women and $53 \%$ of men). Prevalences by country are shown in online annex 4.

\section{DISCUSSION}

The ECCTS offers, for the first time, comparable data on the work and health status of workers in the formal and informal economy in the six Spanish-speaking Central American countries, based on representative national samples. Among the initial findings, the survey underscores the low quality of a large part of employment in Central American countries, with three out of four members of the workforce lacking social security, a third being self-employed and almost 1 out of 10 salaried employees working without either a written or oral contract.

The ECCTS provides a reference measure for future monitoring of employment conditions across countries, as has been recently advocated. ${ }^{23}$ Thus, our findings highlight the magnitude of some characteristics related to informal employment in the region, such as the scarce extent of social security coverage, work without contract or work more than $48 \mathrm{~h}$ per week. As pointed out by the ILO, informal employment is a global problem, characterised basically by tasks performed outside of labour legislation and social protections. ${ }^{24}$ The ECCTS data suggest that there is a north-south division in Central America, with poorer employment conditions in the north of the region (Guatemala, El

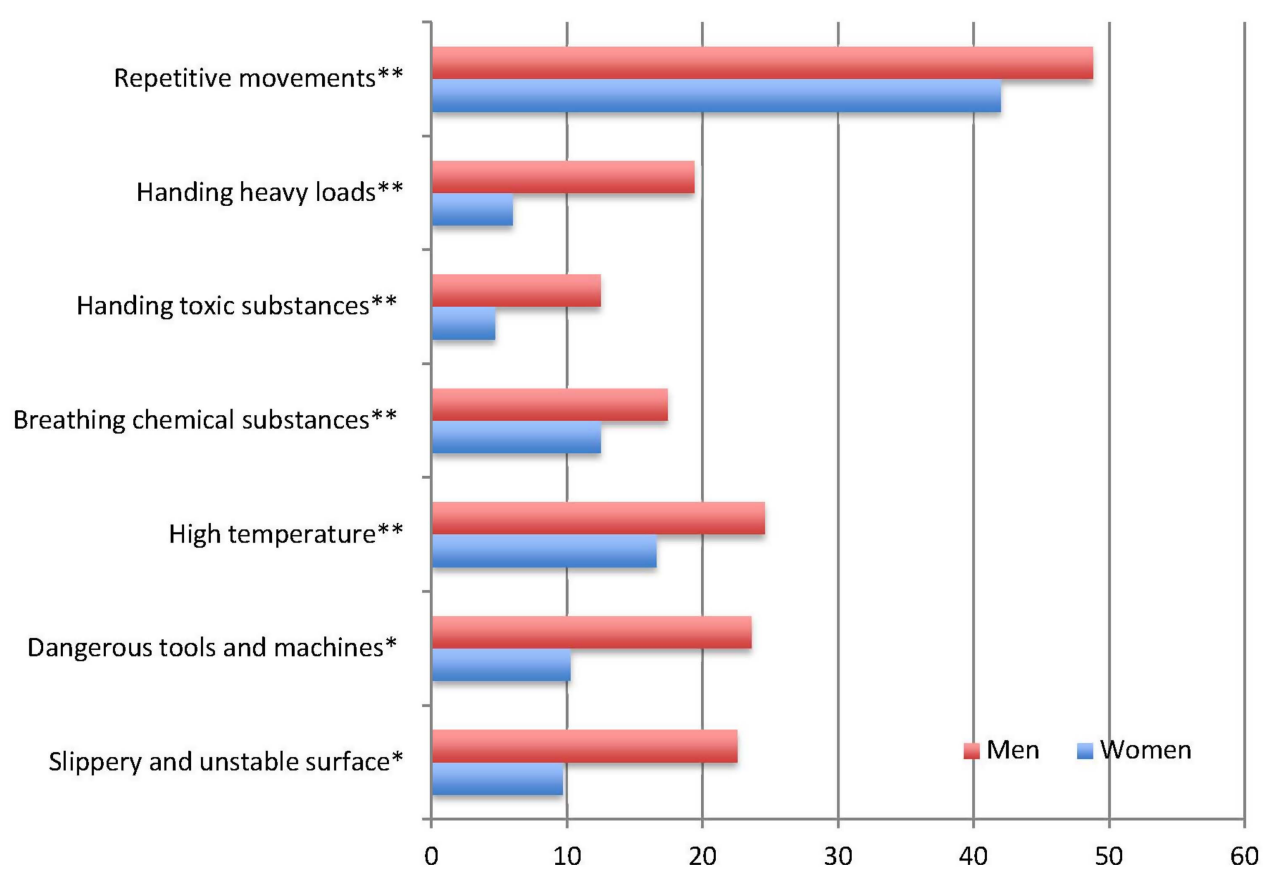

Figure 3 Working conditions risk factors by sex at regional level. The First Central American Working conditions and Health Survey, 2011 $\left(n=12\right.$ 024). *Always or very often; ${ }^{* *}$ more than half working day. 
Figure 4 Health-related problems by sex at regional level. The First Central American Working conditions and Health Survey, $2011(n=12024)$.

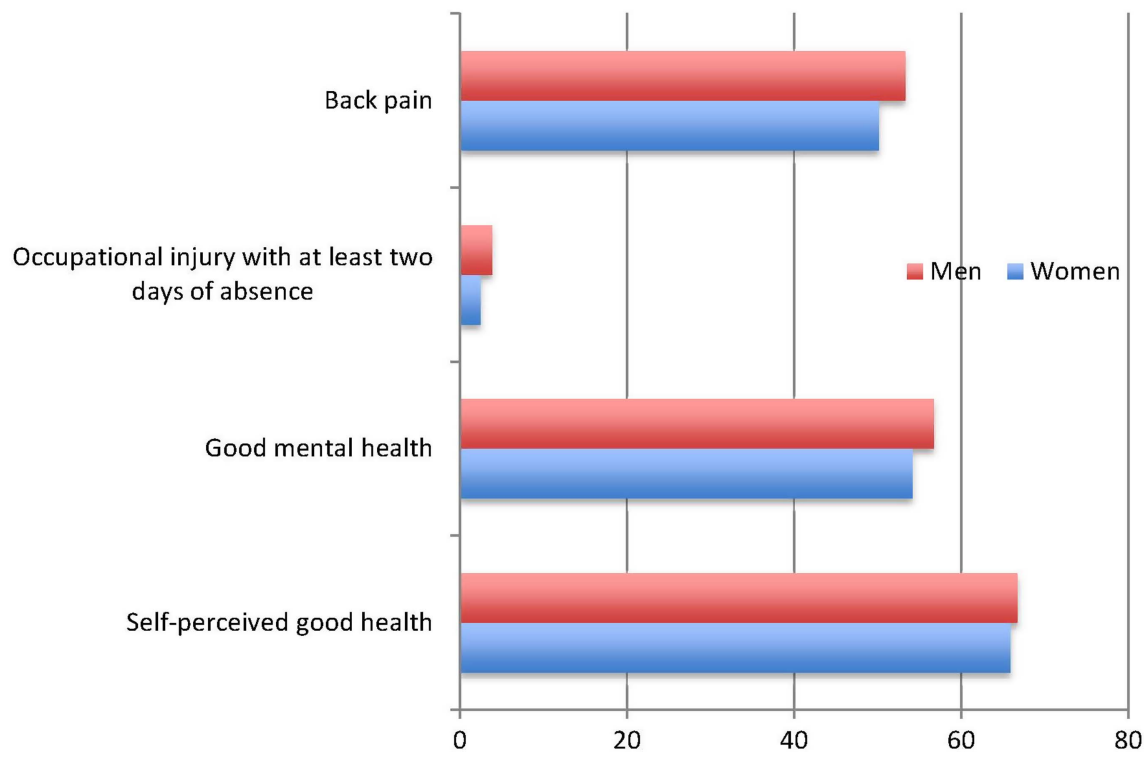

Salvador and Honduras), better ones in the south (Costa Rica and Panama) and Nicaragua somewhere in between. This southnorth gradient could be explained by employment conditions (contract type, social protections, etc.), mostly related to a specific country's legal framework and its enforcement. In this sense, the southern part of Central America could be considered to be in transition towards a decent job agenda and social protection floor. ${ }^{25}$ Future studies are needed to assess this hypothesis.

Regarding working conditions, the high level of perceived exposure to repetitive movements is noteworthy among men and women. This percentage is similar to the recent findings in Finland (44.3\%), France (44.2\%) and Spain (40.9\%). ${ }^{11}$ More in-depth analyses of the ECCTS will help elucidate this finding. Interestingly, the CUPID study (a study of musculoskeletal disorders in office workers and nurses in 18 countries) showed Costa Rica and Nicaragua to have some of the highest prevalences of musculoskeletal disorders. ${ }^{26}$ Another finding that merits highlighting is exposure to high temperatures at work, particularly in Guatemala, Honduras and El Salvador. Occupational heat exposure is becoming an increasingly important issue on the climate change agenda, and concerns about heat exposure among Central American workers have been raised. ${ }^{27}$ Notably, in Central America heat exposure has been identified as a possible causal factor in an ongoing occupational epidemic of chronic kidney disease of unknown etiology. ${ }^{28} 29$

In relation to health, the overall percentage of Central American workers who perceived themselves as being in good health was high, approximating that of OECD countries in 2009: $67 \%$ of women and $72 \%$ of men. ${ }^{30}$ However, the range was wide, from only $50 \%$ in Nicaragua to around $85 \%$ in Panama. Differences between countries were also large for perceived good mental health, ranging from $46 \%$ in Guatemala to $86 \%$ in Panama. More analyses of the ECCTS will help elucidate this finding. Future studies based on this survey will explore associations between self-reported health and working conditions, ${ }^{31}$ and also how social status models the selfreporting ${ }^{32}$ in the context of developing countries.

The low figures reported for occupational injuries are surprising: around $3 \%$ overall for injuries with at least 2 days of absence, which contrasts with an ILO estimation for the region including injury causing at least 3 days absence from work between $12.1 \%$ (Costa Rica) and 17.1\% (Guatemala). ${ }^{33}$ This result also seems to be at odds with the high percentage (over 50\%) of back pain in the previous 4 weeks, a health problem often attributed to overexertion at work. Although the wording for this questionnaire item was based on the ILO Manual of Occupational Injury Statistics, ${ }^{20}$ we believe that its interpretability among Central American workers needs to be re-examined. As Guiffrida and colleagues urged, Latin America needs more consistent and standardised occupational injury surveillance systems. ${ }^{34}$

Our survey could have been affected by selection bias. The response rate was lowest in Costa Rica, which was the first country surveyed. A lesson learned in Costa Rica was to time the interviews so that workers are home and have time and energy to respond. The appropriate time for interview depends on the type of labour, and this factor was more strictly taken into consideration in the countries surveyed subsequently. There were two incidents where the initially selected segment could not be reached due to severe climatic conditions. In these cases, the segments were substituted by a nearby similar segment and this likely had little impact on the overall sampling. The experience gained in the ECCTS will certainly allow for logistical improvements in future surveys, but we feel confident that the overall sampling design and randomisation process decreased selection bias and, together with the weighting performed (according to each country's population distribution), increased cross-country comparability. In fact, there were only small percentage differences when the last census data available were compared with the weighted sample for each country and Central America overall (see online annex 5). The few significant differences $(\mathrm{p}<0.05)$ by sex and economic sector in Costa Rica, Nicaragua, Honduras and Central America are mostly due to large sample sizes of the censuses.

Furthermore, the ECCTS includes only workers aged 18 years and older, which leaves youth workers out of the sample, many of whom work as informal employees. This criterion was adopted because 18 years is the official majority of age, and ethical issues limited our access to this subgroup for interviewing. Ideally, the age limit should be lowered in future surveys.

Misclassification bias could have occurred in relation to selfreported exposures and health status since both are determined by personal expectations and knowledge. Furthermore, except for the General Health Questionnaire, ${ }^{22}$ items included in our questionnaire are not validated. However, our pilot study 
allowed us to linguistically adapt the items to each Central American country. Also, having trained interviewers conduct the survey and doing so in the workers' homes is a strength of the study avoiding information bias, as respondents would be more likely to respond openly than if the interview had been conducted at the workplace. In addition, direct data entry and online transmission to a central facility in San José, where data were checked, on a daily or more frequent basis guarded against significant data errors. Finally, in the context of informal employment, individuals may be engaged in various jobs, each with its own hazards, and this may not have been measured since questions only focused on the job in which individuals spent the greatest number of hours.

The limitations of this survey are counterbalanced by several strengths. Most importantly, the ECCTS is the first such study in this region using a solid sample design, the same questionnaire and same procedures in all six countries. The development and completion of a sound survey of working conditions and health in Central America represents a significant step towards the development of a permanent regional information system in working conditions and health that could provide reliable data for informed national and regional planning and assessment, and the creation of evidence-based policies directed at preventing occupational risks and promoting workers' health. While national surveys like Argentina, Uruguay, Chile or Colombia have intrinsic value for specific countries, regional surveys like this have added value, permitting a broader view by allowing comparisons between countries within the region. In the context of the European surveys, both the general situation in Europe and the differences between member states are considered during evaluation of problems and achievements. In the context of Central American integration efforts, the advancement of regional tools and policies to improve working and health conditions is a priority.

\author{
Author affiliations \\ ${ }^{1}$ Centro de Investigación en Salud Laboral (CISAL), Universitat Pompeu Fabra, \\ Barcelona, Spain \\ ${ }^{2}$ CIBER of Epidemiology and Public Health, Spain \\ ${ }^{3}$ IMIM Parc Salut Mar., Barcelona, Spain \\ ${ }^{4}$ Programa Salud, Trabajo y Ambiente en América Central (SALTRA), Central \\ American Institute for Studies on Toxic Substances, Universidad Nacional, Heredia, \\ Costa Rica \\ ${ }^{5}$ The University of Texas School of Public Health (UT), Houston, USA \\ ${ }^{6}$ National Institute for Occupational Safety and Health (NIOSH), Atlanta, USA \\ ${ }^{7}$ Instituto Nacional de Seguridad e Higiene en el Trabajo (INSHT). Ministerio de \\ Empleo y Seguridad Social, Madrid, Spain \\ ${ }^{8}$ Instituto Sindical Trabajo, Ambiente y Salud (ISTAS), CCOO, Valencia, Spain
}

Collaborators Emily Felt, María López, Centro de Investigación en Salud Laboral (CISAL), Universitat Pompeu Fabra (Barcelona); Carlos Santos, Organización Iberoamericana de Seguridad Social (OISS); David Gimeno, The University of Texas School of Public Health (UT) in San Antonio, USA; Marianela Rojas, Freddy Briceño and Patricia Monge, Programa Salud y Trabajo en América Central (SALTRA), Universidad Nacional, Costa Rica; Norma Osiris, SALTRA, Universidad de El Salvador; Carlos Meléndez; Consultor para SALTRA, Universidad de San Carlos (USAC), Guatemala; Lino Carmenate, SALTRA, Facultad de Medicina, Universidad Nacional Autónoma de Honduras (UNAH); Indiana López and Aurora Aragón, SALTRA, Centro de Investigación en Salud, Trabajo y Ambiente (CISTA), Universidad Nacional Autónoma de Nicaragua (UNAN-León); Pedro Vinda, SALTRA, Universidad de las Américas y Caja del Seguro Social, Panamá; Nancy Piedra, Universidad de Costa Rica, San José, Costa Rica

Contributors All coauthors conceptualised the survey and supervised fieldwork. FGB drafted the different versions of the article, and all coauthors critically revised the article for important intellectual content.

Funding This study was partially funded by a contract between the Organización Iberoamericana de Seguridad Social and the Universidad Nacional de Costa Rica
(Heredia), and also by Fogarty International Center, U.S. National Institutes of Health grant (D4TW00064).

\section{Competing interests None.}

Ethics approval Institutional review boards of the Universidad Nacional in Costa Rica and The University of Texas Health Science Center at Houston.

Provenance and peer review Not commissioned; externally peer reviewed.

Data sharing statement Data set and questionnaire are available upon request.

\section{REFERENCES}

1 United Nations Development Program. Human Development Index. http://hdr.undp. org/en/statistics/hdi/ (accessed Sep 2013).

2 Banco Centroamericano de Integración Económica (BCIE). Avances y desafío de la integración Centroamericana. Una revision a 50 años de historia, 2010. http://www. bcie.org/uploaded/content/category/1251651498.pdf (accessed Sep 2013).

3 Wesseling C, Aragon A, Morgado $\mathrm{H}$, et al. Occupational Health in Central America. Int I Occup Environ Health 2002;8:125-36.

4 United Nations. Millenium Development Goals. 2013. http://www.un.org/ millenniumgoals (accessed Sep 2013).

5 World Health Organization. Workers' Health: Global Plan of Action 2008-2017. 2007. http://www.who.int/occupational_health/WHO_health_assembly_en_web.pdf (accessed Sep 2013)

6 World Health Organization. Workers' Health: Global Plan of Action 2008-2017. 2007. http://www.who.int/occupational_health/WHO_health_assembly_en_web.pdf (accessed Sep 2013)

7 Organización Iberoamericana de la Seguridad Social. Estrategia Iberoamericana de Seguridad y Salud en el Trabajo 2010-2013. 2009. http://www.oiss.org/estrategia/ (accessed Sep 2013).

8 Organización Internacional del Trabajo. Panorama Laboral 2012. Lima: OIT/Oficina Regional para América Latina y el Caribe, 2012.

9 Aragón A, Partanen T, Felknor S, et al. Social determinants of workers' health in Central America. Int I Occup Environ Health 2011;17:230-7.

10 Choi BC, Tennassee LM, Eijkemans GJ. Developing regional workplace health and hazard surveillance in the Americas. Rev Panam Salud Publica 2001;10:376-81.

11 European Foundation for the Improvement of Living and Working Conditions. Fifth European Working Conditions Survey—Overview report. http://www.eurofound. europa.eu/publications/htmlfiles/ef1182.htm (accessed Sep 2013).

12 Ministerio de la Protección Social. Gobierno de Colombia 2007. Primera Encuesta Nacional de Condiciones de Salud y Trabajo en el Sistema General de Riesgos Profesionales. http://www.minsalud.gov.co/Documentos\%20y\%20Publicaciones/ ENCUESTA\%20SALUD\%20RP.pdf (accessed Sep 2013).

13 Superintendencia de Riesgos en el Trabajo. Ministerio de Trabajo, Empleo y Seguridad Social. Gobierno de Argentina. Encuesta Nacional de Trabajo, Condiciones y Medioambiente laboral. 2010. http://www.srt.gob.ar/inicio/srt/ contenidos-srt/publicaciones/publicaciones (accessed Sep 2013).

14 Ministerio de Salud, Gobierno de Chile. Primera encuesta nacional de empleo, trabajo, salud y calidad de vida de los trabajadores y trabajadoras en Chile (ENETS 2009-2010). 2011. http://epi.minsal.cl/estudios-y-encuestas-poblacionales/ encuestas-poblacionales/enets/presentacion-enets/ (accessed Sep 2013).

15 Martinez D, Crego A. I Encuesta sobre Condiciones de Trabajo, Seguridad y Salud en el Trabajo en Uruguay. Informe general. Universidad Rey Juan carlos (España) y Universidad de la República de Uruguay. Agencia Española de Cooperación Internacional para el desarrollo (AECID), 2013.

16 Trejas JD, Del Cid M. Decent work and informal economy in Central America. Working paper No. 7. Geneva: International Labour Organization, 2002. http://www.ilo.org/integration/resources/papers/WCMS_079110/lang—en/index.htm (accessed Sep 2013).

17 Gallup Europe. 5th European Working Conditions Survey's Weighting Report. Working document for The European Foundation for the Improvement of Living and Working Conditions. 2010. http://www.eurofound.europa.eu/surveys/ewcs/2010/ documents/weighting.pdf (accessed Sep 2013).

18 Benavides FG, Zimmermann M, Campos J, et al. Conjunto mínimo básico de ítems para el diseño de cuestionarios sobre condiciones de trabajo y salud. Arch Prev Riesgos Labor 2010;13:13-22.

19 Instituto Nacional de Seguridad e Higiene en el Trabajo. Gobierno de España. VII Encuesta Nacional de Condiciones de Trabajo. http://encuestasnacionales.oect.es (accessed Sep 2013).

20 Taswell K, Wingfield-Digby P. Occupational injuries statistics from household surveys and establishment surveys. Geneva: International Labour Office, 2008.

21 Sánchez-López MP, Dresch D. The 12-Item General Health Questionnaire (GHQ-12): Reliability, external validity and factor structure in the Spanish population. Psicothema 2008;20:839-43.

22 International Labour Organization. International Standard Classification of Occupations ISCO-2008. http://www.llo.org/public/spanish/bureau/stat/isco/index. htm (accessed Sep 2013). 
23 Benach J, Puig-Barrachina V, Vives A, et al. The challenge of monitoring employment-related health inequalities. J Epidemiol Commm Health 2012;66:1085-7.

24 International Labour Organization. Decent work and the transition to formalization: recent trends, policy debates and good practices. 2008. http://www.ilo.org/ safework/info/publications/WCMS 110314/lang--en/index.htm (accessed Sep 2013).

25 International Labor Organization. Measuring informality: a statistic manual on the informal sector and informal employment. http://www.ilo.org/global/

statistics-and-databases/WCMS_182299/lang_en/index.htm (accessed Sep 2013).

26 Coggon D, Ntani G, Vargas-Prada S, et al. International variation in absence from work attributed to musculoskeletal illness: findings from the CUPID study. Occup Environ Med 2013;70:575-84.

27 Kjellstrom T, Crowe J. Climate change, workplace heat exposure, and occupational health and productivity in Central America. Int J Occup Environ Health 2011;17: 270-81.

28 Ramirez-Rubio 0, McClean MD, Amador JJ, et al. An epidemic of chronic kidney disease in Central America: an overview. J Epidemiol Community Health 2013:67:1-3.
29 Wesseling C, Crowe J, Hogstedt C, et al. The Epidemic of Chronic Kidney Disease of Unknown Etiology in Mesoamerica: A Call for Interdisciplinary Research and Action. Am J Public Health 2013;103:1927-30.

30 OECD. Health at a glance 2011. OECD Indicators. OECD Publishing, 2011. http://dx.doi.org/10.1787/health_glance-2011-en (accessed Sep 2013).

31 Borrell C, Muntaner C, Benach J, et al. Social class and self-reported health status among men and women: what is the role of work organisation, household materia standards and household labour? Soc Sci Med 2004;58:1869-87.

32 Miilunpalo S, Vuori I, Oja P, et al. Self-rated health status as a health measure: the predictive value of self-reported health status on the use of physician services and on mortality in the working-age population. J Clin Epidemiol 1997;50:517-28

33 Hämäläin P, Takala J, Saarela KL. Global estimates of occupational accidents. Saf Sci 2006:44:137-56.

34 Guiffrida A, lunes RF, Savedoff W. Occupational risk in Latin America and the Caribbean economic and health dimensions. Health Policy and Plan 2002;17:235-48. 